\title{
DISSOCLADELLA? CHAHTORSHIANA RASHIDI \& SCHLAGINTWEIT N. SP., A NEW DASYCLADALE (GREEN ALGAE) FROM THE PALEOCENE OF IRAN
}

\author{
Felix Schlagintweit ${ }^{1 *}$, Koorosh Rashidi², Hamed Yarahmadzahi ${ }^{3}$, Sharam Habibimood ${ }^{3}$, \\ Mahnaz Amirshahkarmi ${ }^{4}$, Hossain Ahmadi $^{4}$ \& Hossain Khokan ${ }^{4}$
}

Received: 02 June 2019 / Accepted: 21 June 2019 / Published online: 08 July 2019

\begin{abstract}
A new Dasycladale is described as Dissocladella? chahtorshiana Rashidi \& Schlagintweit n. sp. from Selandian carbonates of Mount Chah Torsh, Central Iran (type locality). Other occurrence is from the Sistan Suture Zone of Eastern Iran (Selandian?, Thanetian?). The medium-sized taxon displays cylindrical to slightly claviform thalli with a relatively large main axis bearing alternating primaries of variable shape. The latter show either slowly widening towards the distal end or are club-shaped displaying very short secondaries. The morphological variability of the primaries, both typical and atypical for Dissocladella, account for some doubts on the generic assignment of the new species. Dissocladella? chahtorshiana occurs in bioclastic packstones with Cymopolia mayaense Johnson \& Kaska, Acroporella cf. anceps Segonzac, Halimeda sp., and benthic foraminifera (e.g., soritiids) at its type locality.
\end{abstract}

Keywords: Green algae, Yazd Block, Paleogene, taxonomy, biostratigraphy

\section{INTRODUCTION}

Paleocene shallow-water carbonates are known from different parts (or tectonic zones) of Iran: the Kopet-Dagh Basin, NE Iran (e.g., Rahaghi, 1983; Rivandi and Moosavizadeh, 2015; Salahi et al., 2018), the Sistan Suture Zone, E Iran (e.g., Rahaghi, 1983; Tirrul et al., 1983), Central Iran (e.g., Deloffre et al., 1977; KhosrowTehrani, 1987), or Zagros Zone, SW Iran (e.g., James and Wynd, 1965; Kalantari, 1976; Lasemi et al., 2007). Micropaleontological, taxonomic, and biostratigraphic studies [referring to Paleogene Shallow Benthic Zones (SBZ) of Serra-Kiel et al., 1998] of these rocks are rare and date back mostly to the seventies and eighties. Being rich in dasycladaleans and larger benthic foraminifera much more attention has been given to the latter group (Kalantari, 1976; Rahaghi, 1978, 1980, 1983). Data on Paleogene dasycladaleans from Iran are scarce (e.g., Deloffre et al., 1977; Barani et al., 2017). In the present contribution a new Dasycladale is described from Paleocene carbonates of Central Iran in the wider area of Yazd (type locality), and the Sistan Suture Zone of Eastern Iran (Fig. 1).

\section{STUDIED SECTIONS}

The studied material comes from two localities, Kuh-eChah Torsh in Central Iran, representing the type-locality of Disscocladella? chahtorshiana n. sp., and Kuh-ePatorgi in Eastern Iran. As Kuh means Mount in Persian, the localities are also named Mount Chah Torsh and Mount Patorgi sections.

\section{Kuh-e-Chah Torsh section}

The Mount Chah Torsh section is located about $55 \mathrm{~km}$ southeast of Mehriz, near Yazd city (Fig. 2/1). In previ- ous works this locality is named Kuh-é-Tchahtorch (Deloffre et al., 1977), Tchah-Torch (Khosrow-Tehrani, 1987), Kamar-e-Chahtorsh (Nabavi, 1972), and Kuh-eChah Torsh (Majidifard and Vaziri, 2000). Geotectonically, the study site is part of the Central Iranian Microcontinent, namely the Yazd Block (e.g., Takin, 1972) (Fig. 1). Palaeogeographically it is part of the former Northern Neotethyan margin. It is worth mentioning that in the Geological Map of Nabavi (1972) Mount Chah Torsh is shown build up only of Cretaceous strata. The Paleogene carbonates forming rather steep slopes (Figs. 2/2, 4) and reaching to the top of the mountain were instead correctly included in the map of Majidifard and Vaziri (2000). The highest point of Mount Chah Torsh reaches $2.304 \mathrm{~m}$ above sea-level, and the surrounding plain is about 1.870 $\mathrm{m}$ a.s.l. Mount Chah Torsh has an NW-SE directed extension of about $6.6 \mathrm{~km}$, with a width of about $3.7 \mathrm{~km}$.

The exposed sedimentary sequence starts with Lower Cretaceous "Orbitolina" Limestone (= Taft Formation) containing Dictyoconus? pachymarginalis Schroeder (Fig. 2/2a) and Mesorbitolina gr. parva (Douglass)texana (Roemer). The base of the Taft Formation is not exposed (hidden under alluvial deposits). The two mentioned taxa were observed within the whole part indicating that the Taft Formation at Mount Chah Torsh is Gargasian in age (Schlagintweit and Wilmsen 2014, with references therein). It is followed with erosional contact by clastic deposits, and Upper Cretaceous sandy limestones containing bryozoans, and the Larger Benthic Foraminifera Orbitoides gensacicus (Leymerie) (Fig. 2/2b), Canalispina iapygia Robles-Salcedo, Vicedo, Parente \& Caus, Sirelina orduensis Meriç \& Inan, Sirtina ornata (Rahaghi), Orbitoides gruenbachensis Papp, and more rarely Omphalocyclus macroporus (Lamarck). These deposits can be assigned to the late Maastrichtian (Robles-Salcedo et al., 2019). Above the last sample with orbitoidids assigned to the late Maastrichtian (Ah 73), an

\footnotetext{
${ }^{1}$ Lerchenauerstr. 167, 80935 Munich, Germany, *Corresponding author: felix.schlagintweit@gmx.de 


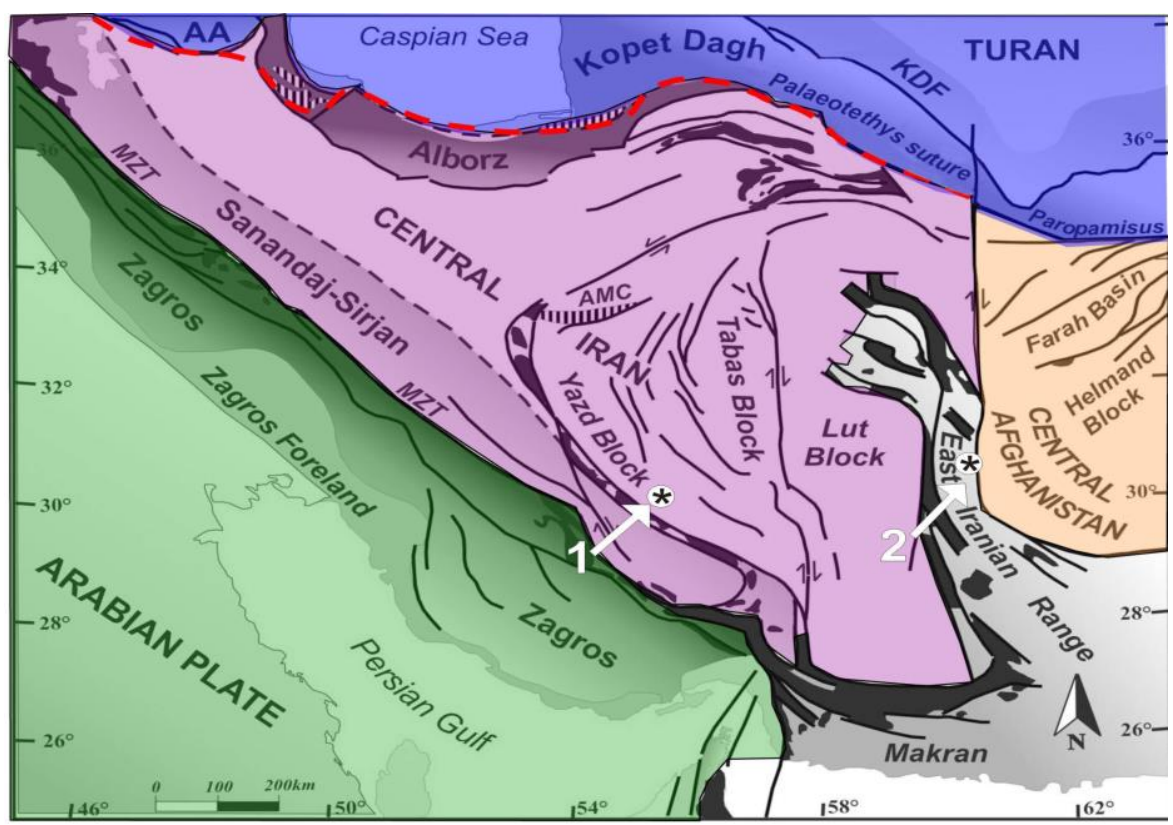

Fig. 1 Tentative location of the Kuh-e-Chah Torsh (1) and Kuh-e-Patorgi (2) sections plotted on the tectonic map of Iran (modified from Zanchi et al., 2009). Abbreviations: AA = Anatolian-Armenian Block, AMC = Anarak Metamorphic Complex, KDF $=$ Kopeh Dagh Foredeep, MZT = Main Zagros Trust).

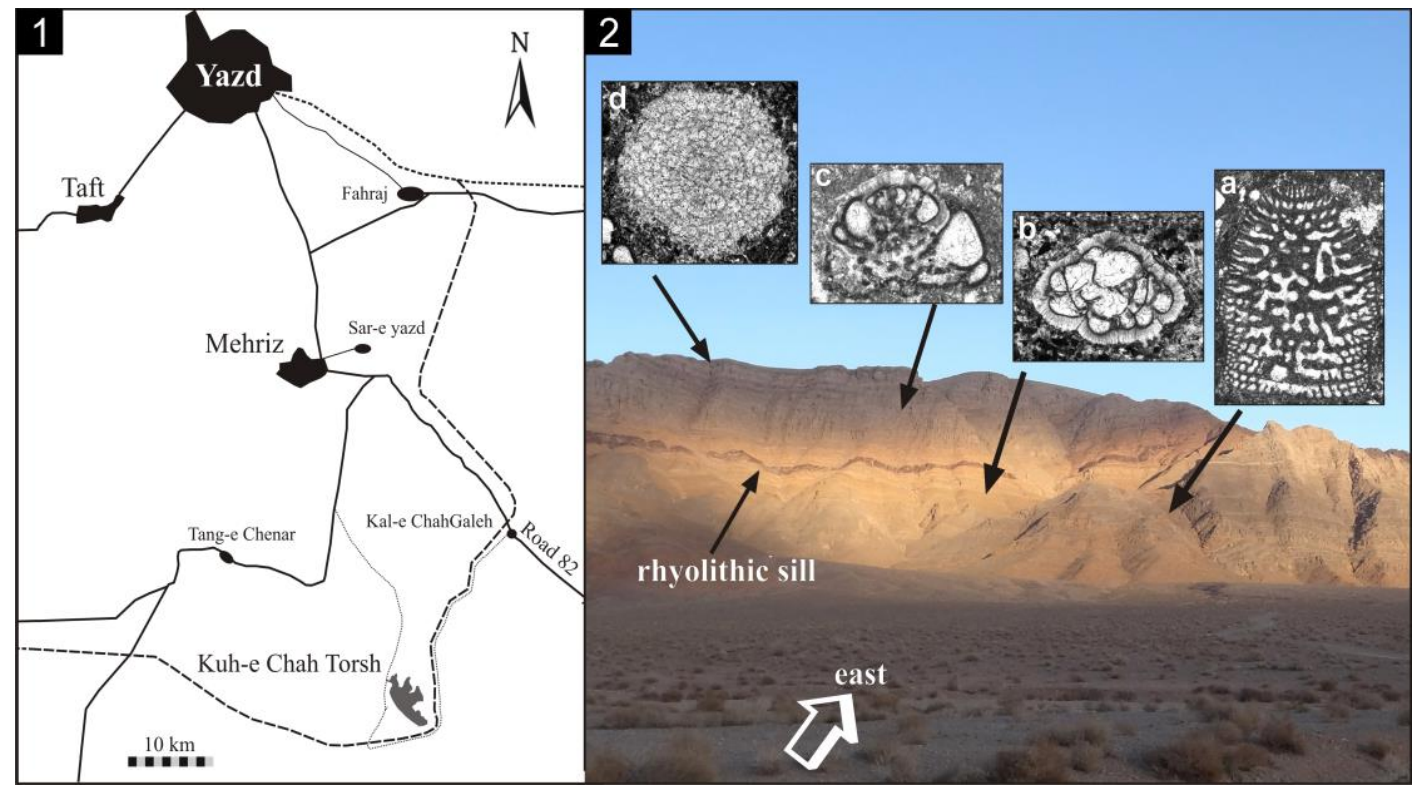

Fig. 2 Location (1) and field view (2) of Kuh-e-Chah Torsh, the type-locality of Dissocladella? chahtorshiana n. sp. For the position within the territory of Iran see figure 1. Larger Benthic Foraminifera in (2): Dictyoconus? pachymarginalis Schroeder (?late Bedoulian-Gargasian?, a), Orbitoides gensacicus (Leymerie) (late Maastrichtian, b), Sistanites iranicus Rahaghi (Selandian, c), Orduella sphaerica Sirel (Selandian, d).

interval of sandy marls $(0.8 \mathrm{~m}$ to $1.0 \mathrm{~m})$ follows lacking any sample data. Most likely it represents an emersion horizon at the K-Pg boundary interval (Figs. 3-4). The lowermost sample of the following mixed carbonaticsiliciclastic marine bed (Ah 74), documents a new transgression, and contains textulariids and rotaliids, among Rotorbinella detrecta Hottinger. This facies directly grades into grey carbonates displaying nodular habitus. These contain abundant rather thick-walled miliolids, (Ankarella, Haymanella), the agglutinating taxon Kolchidina paleocenica (Cushman), and bryozoans, assigned to the Danian (e.g., Sirel, 1999). Especially the presence of green algae (Ovulites morelleti Elliott, Terquemella sp., Cymopolia cf. barattoloi Parente), lacking in the late Maastrichtian samples is worth mentioning. The early Danian algal-miliolid limestones display infiltration of Microcodium aggregates at the top connected to an emersion horizon (see Košir, 2004; Kabanov et al., 2008, for origin and interpretation).

Upwards it is followed by alluvial fan conglomerates, unfossiliferous reddish sandstones, mudstones exhibiting fine cracks and black pebble formation (mud-flat deposits), subtidal grain-packstones with miliolids and algae (subtidal lagoon), and intercalated lensoidal dolomite 
bodies. The repetitive appearance of (sandy) mudstones and lagoonal grain/packstones indicates cyclic sedimentation due to oscillating sea-level (Trangressive-Regressive cycles; TCR). In the lower part of the cycles a several metres (average $35-40 \mathrm{~m}$ ) thick rhyolitic sill is intercalated (see Figs. 2, 4). This unit is followed by a package of limestones that correspond from a microfacies point of view with the subtidal beds of the T-R cycles. These are followed upwards by thick-bedded to massive limestones reaching up to the summit of Mount Chah Torsh. The diversification of benthonic foraminifera and calcareous algae starts in the middle to upper part increasing markedly in the last third of this unit. From this locality Deloffre et al. (1977) reported Cymopolia heraki Gušić (= Cymopolia mayaense Johnson \& Kaska acc. to Deloffre and Génot 1982), Clypeina sp., and Acroporella cf. anceps Segonzac (see also Khosrow-Tehrani, 1987). From this upper unit, the new Dasycladale Dissocladella? chahtorshiana is described (Fig. 4). The typical microfacies is a bioclastic packstone containing dasycladaleans (Dissocladella? chahtorshiana n. sp. Cymopolia mayaense Johnson \& Kaska, Acroporella? anceps Segonzac, Clypeina elliotti Beckmann \& Beckmann, and others), halimedaceans, benthonic foraminifera (rotaliids, and soritoids), and some gastropods (Fig. 5A-C). The coordinates of the Mount Chah Torsh section at its base are $31^{\circ} 14^{\prime} 37.28^{\prime \prime} \mathrm{N}$, and $54^{\circ} 33^{\prime} 43.27^{\prime \prime} \mathrm{E}$.

The larger benthic foraminifera Sistanites iranicus Rahaghi is among the most common taxa in the upper part of the section (Figs. 2/2c, 3). Its first occurrence is (in accordance with literature data from other regions) tentatively used as the separation of SBZ 1 and SBZ 2 sensu Serra-Kiel et al. (1998) at Mount Chah Torsh. The SBZ 2 includes an interval from the latest Danian to the lower/middle part of the Selandian (e.g., Papazzoni et al., 2017, fig. 1). Near the top of the section we observed Orduella sphaerica Sirel (Fig. 2/2d) that is assigned the same stratigraphic interval as for S. iranicus (Sirel 2012, fig. 11). In conclusion, there is no evidence that the Paleogene carbonates exposed at Mount Chah Torsh reach into the Thanetian. Based on these statements, the interval containing Dissocladella? chahtorshiana n. sp. (Fig. 4) can be assigned to the Selandian.

\section{Kuh-e-Patorgi section}

It is located SE of Bandan village, about $215 \mathrm{~km}$ distance to Zahedan, the central province city (Zahedan), and close to the border to Afghanistan. Based on Bandan map 1:100000 (Eftekhar Nezhad et al., 1990), the oldest unit in the section is represented by the Sefidabeh Formation that consists of volcanoclastic deposits. It is conformably overlain by the Paleogene Palang Formation, subdivided into two limestone members separated by conglomerates. Geotectonically, the study area is located between the Lut Block in the west and Helmand (or Afghan) Block to the east (Fig. 1). It is known as East Iran Flysch Zone or Sistan Suture Zone and mainly includes ophiolitic mélanges and Upper Cretaceous to Paleogene sediments (Tirrul et al., 1983). Palaeogeographically it is part of the former Northern Neotethyan margin. At the Kuh-e-Patorgi section the new alga Dissocladella? chahtorshiana $\mathrm{n}$. $\mathrm{sp}$. is much less frequent than at its type-locality. It occurs in bioclastic packstones with dasycladaleans, e.g., Rostroporella oviformis Segonzac, benthonic foraminifera (rotaliids, soritoids) (Fig. 5D). In the northwestern vicinity of the Kuh-e-Patorgi section, Disscocladella? chahtorshiana n. sp. may be rather frequent in some layers (Fig. 5E). Based on the occurrence of Rotorbinella detrecta Hottinger in the layers below, and the appearance of the rhodophycean alga Distichoplax biserialis Dietrich in layers above, the samples with Dissocladella? chahtorshiana n. sp. can be assigned to the late Selandian-early Thanetian interval at Kuh-e-Patorgi (Hottinger, 2014). The Kuh-e-Patorgi section still needs detailed micropaleontological studies. The coordinates of the section base are $31^{\circ} 22^{\prime} 59.10^{\prime \prime} \mathrm{N}$, and 6049'36.58"E.

\section{MATERIAL AND DEPOSITORY}

The analyses of the Paleocene limestones refer exclusively to thin-sections. The specimens illustrated in the present paper are from three thin-sections. Ah 185 from Kuh-e-Chah Torsh is deposited in the Geosciences Museum of Mashad (in the Geological Survey of North-Iran East territory) under the depository number Gmm13950F70. It is part of a series of 45 thin-sections that have been stored recently at the Museum in the framework of a micropalaeontological study focused on larger benthic foraminifera from Mount Chah Torsh. Thin-section CT 4 from Kuh-e-Chah Torsh and 2pz29 from Kuh-e-Patorgi are stored at the Ardakan Payame Noor University, Iran, in the Rashidi collection.

\section{SYSTEMATICS}

By Rashidi, K. \& Schlagintweit, F.

Phylum Chlorophyta

Class Dasycladophyceae Hoek et al., 1995

Order Dasycladales Pascher, 1931

Family Dasycladaceae Kützing, 1843

Genus Dissocladella Pia in Rao \& Pia, 1936, emend. Bassoullet \& al., 1978

Remarks: The genus Dissocladella Pia has often been used as a waste-paper basket in the past to include dasycladaleans with two orders of laterals among swollen primaries (club-shaped) (e.g., Sokač and Nikler, 1973; Jaffrezo, 1975). With the cylindrical to slightly claviform thallus, the club-shaped primaries, arranged perpendicular to the axis Dissocladella appears the nearest genus exhibiting two orders of laterals where the specimens from the Paleocene of Iran can be assigned (e.g., Jaffrezo, 1975; Bucur et al., 2010). Some reservations are due to other morphologies of the primaries showing only slight and more or less continuous widening. These differences might refer to different parts of the thallus with fertile regions (swollen primaries) as has for example been demonstrated for Suppiluliumaella schroederi by Barattolo (1984). The type-species $D$. savitriae is unique among all species of the genus due to its outer thallus annulation leading to ring-shaped fragments (Rao and Pia, 1936). This feature however has never been considered as being of generic importance (e.g., Radoičić et al., 2005), otherwise Dissocladella would represent a monospecific taxon. 


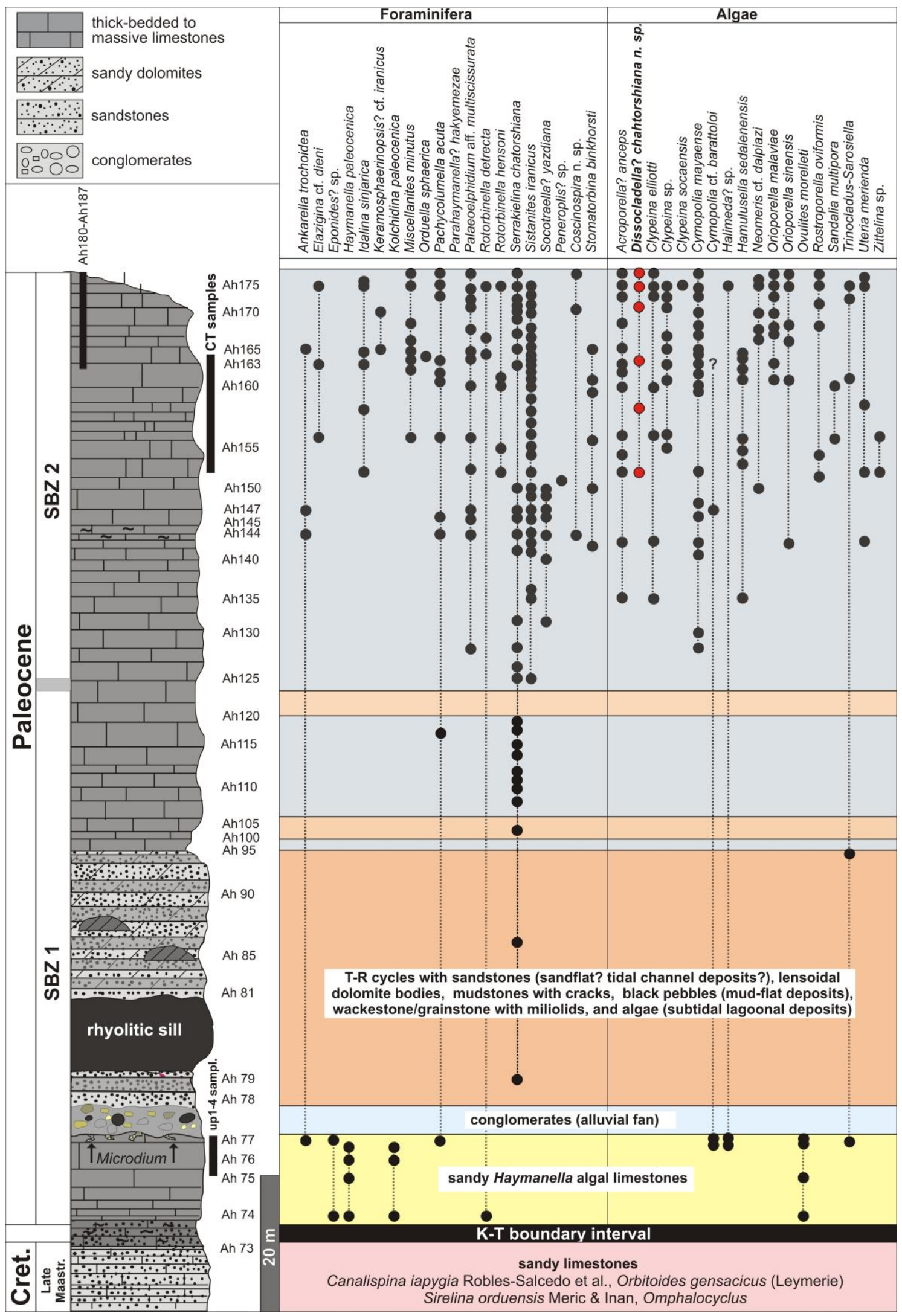

Fig. 3 Simplified lithostratigraphic column of the Kuh-e-Chah Torsh section with position of samples and distribution of benthic foraminifera and calcareous algae. Inferred SBZ zones after Serra-Kiel et al. (1998), Sirel (2012), and Hottinger (2014) (modified from Schlagintweit \& Rashidi, 2019, in press.). 


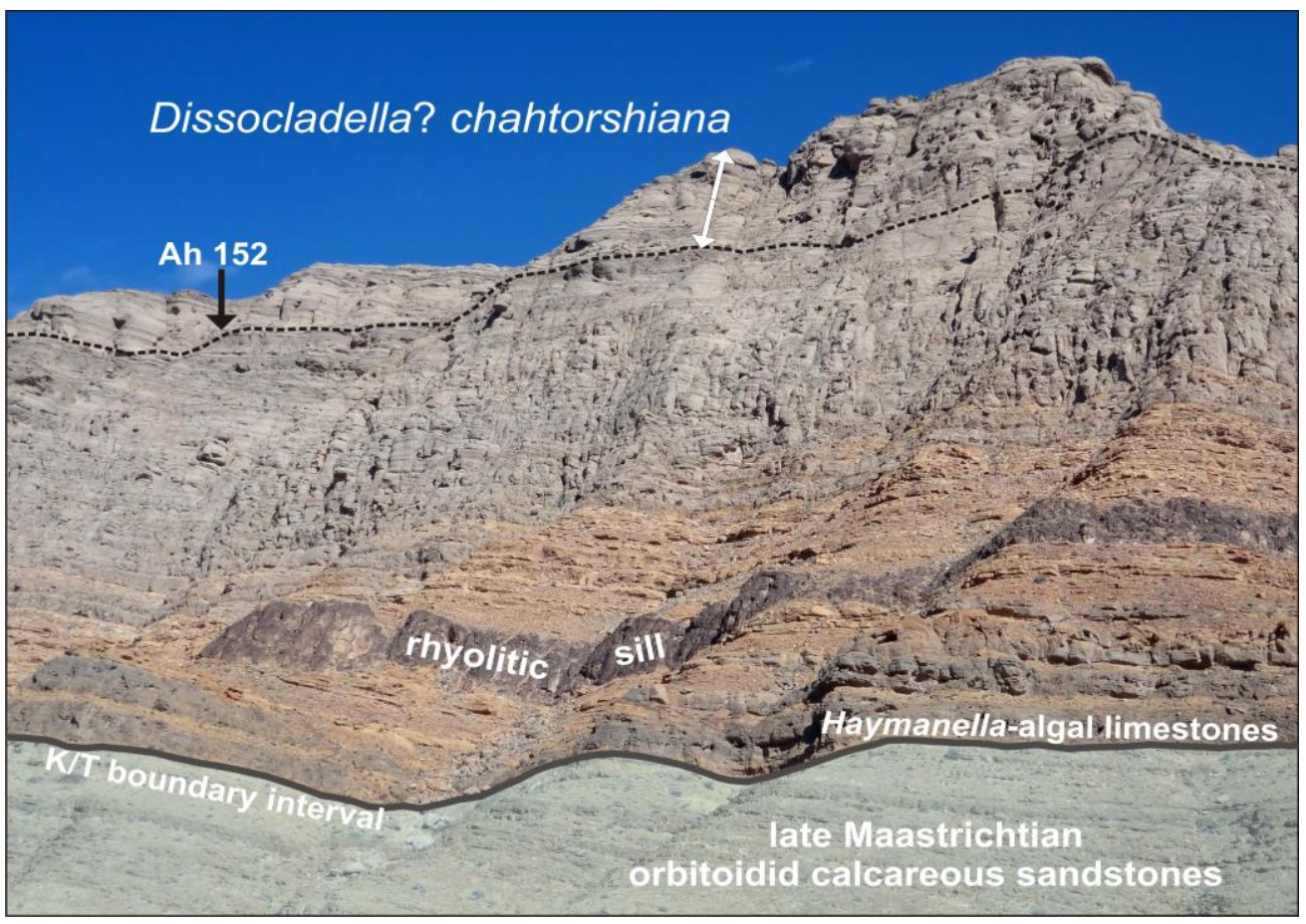

Fig. 4 Close-up view of the south-western slope of Kuh-e-Chah Torsh showing the lithostratigraphic succession and the interval containing Dissocladella? chahtorshiana n.sp.

Dissocladella? chahtorshiana $\mathrm{n} . \mathrm{sp}$.

Figs. 5A-D pars, 6-8

Origin of the name: The name refers to the type-locality Mount Chah Torsh, Central Iran (Figs. 1-3).

Holotype: Oblique section shown in Figure 8C, thinsection CT 4.

Horizon and locality: Selandian carbonates from Mount Chah Torsh, lithostratigraphically not defined (= no formation name assigned).

Description: A medium-sized, well calcified Dasycladale with a cylindrical to slightly clavate thallus (Fig. 7A-B, Fig. 8D). The large main axis of roughly two third of diameter is bordered by a rather smooth surface except common widenings of the proximal part of the laterals, assumed of secondary origin (Fig. 6A, F) (compare Pl. 1, Fig. 3 in Radoičic et al., 2005). The primariy laterals are numerous and regularly alternating between consecutive verticils. In shallow tangential sections they are close-set and of round outline (Fig. 7A-B, lower part). In deep tangential sections they appear of triangular outline (with rounded edges) (Fig. 7B, middle part). The primaries are usually arranged perpendicular to the axis in cylindrical morphologies (Fig. 7B); in slightly claviform morphologies they are slightly inclined upwards (Fig. 8D). The shape of the primaries is variable: slightly widening outwards and without detectable secondaries (Fig. 6A-B) or with a distinct swelling (club-shaped morphology) and secondaries (Fig. 6E-F). Sometimes the swollen part of the primaries are almost touching (or do so) with neighbouring ones. The different morphologies might refer to different parts of the thallus (sterile? fertile?). In transverse or longitudinal sections, two secondaries distinctly shorter than the primaries and widening distally are de- tectable (Fig. 7C-D, E-G). The exact number of secondaries per primary however lateral is unknown. Often they appear as a united micritic diverging masse upon the distal surface of the primaries (Fig. 7C, E, G).

Comparisons: From the Paleogene, the following species of Dissocladella have been described (data from Barattolo, 2002):

D. deserta Elliott (Selandian-Ypresian): D. deserta from the Paleocene of Iraq, and lower Eocene of Egypt (Elliott, $1968)$ is a very small species $(\mathrm{D}=0.39-0.47 \mathrm{~mm})$, and about twelve primaries.

D. gracilis Radoičić (Thanetian of Slovenia, Radoičić, 1991): as name already implies, it represents a very small alga (D: 0.16-0.290 mm, max. $0.368 \mathrm{~mm}$ ) with four primaries.

D. longjangensis $\mathrm{Mu} \&$ Wang (Lutetian of China, $\mathrm{Mu}$ and Wang, 1985): medium-sized species (D up to 0.65 mm, see Kuss and Herbig, 1993, Paleogene of Egypt), and a main axis occupying about half the diameter $(\mathrm{d} / \mathrm{D}$ 0.50-0.55).

D. lunata Segonzac (Thanetian of France, Segonzac, 1979): small sized species (D: 0.282-0.415 mm) with four to six primaries.

D. savitriae Pia (Danian-Thanetian): large-sized and annulated representative of the genus (D: 1.5-2.0 mm) with more than 40 primaries per verticil (Rao and Pia, 1936). D. turnsekae Radoičić (Danian-Selandian of Slovenia, Radoičić, 1998): it represents a very small species ( $\mathrm{D}=$ $0.24-0.35 \mathrm{~mm}$ ) with about eight primaries aligned vertically between successive whorls.

We may also note some resemblances of the lateral morphology with the poorly known Jodotella volpensis described by Segonzac (1976) with two sections from the 

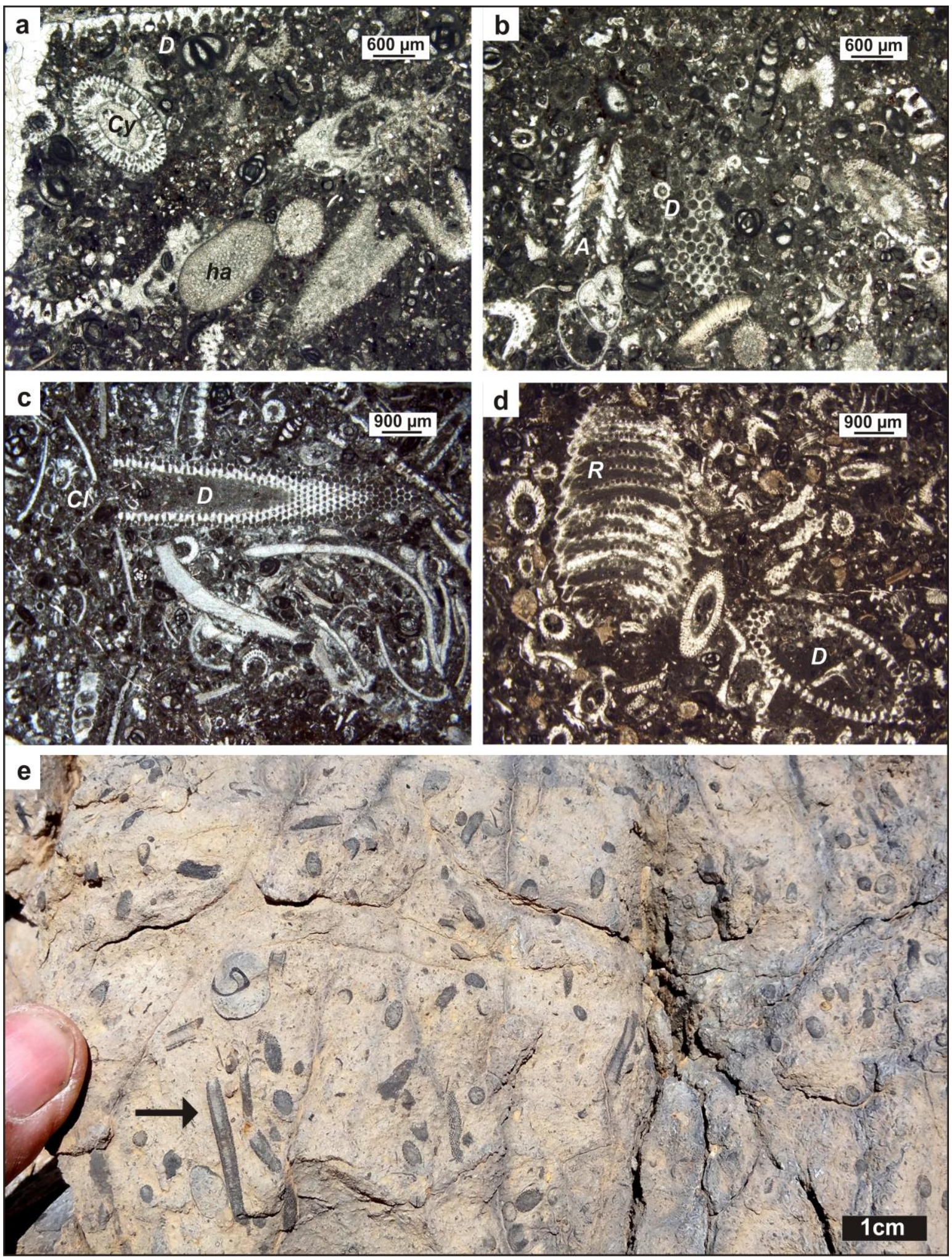

Fig. 5 Typical microfacies of samples with Dissocladella? chahtorshiana n. sp. $(D)$, from the Paleocene of the Kuh-eChah Torsh (a-c) and Kuh-e-Patorgi (d-e) sections. a-b Bioclastic packstone with dasycladalean (e.g., Acroporella? anceps Segonzac, A), halimedacean (ha) algae, gastropods, and porcelaneous benthic foraminifera (e.g., soritoidids). c Bioclastic packstone with dasycladalean algae (e.g., Clypeina elliotti Beckmann \& Beckmann, Cl). d Bioclastic packstone with dasycladaleans (e.g., Rostroporella oviformis Segonzac, $R$ ). Thin-sections: Ah 185 (a-b), CT 4 (c), 2 pz29 (d). e Weathered rock surface with thallus fragments of Dissocladella? chahtorshiana $\mathrm{n}$. sp. The maximum observed length amounts for $~ 17.5 \mathrm{~mm}$ (arrow). Kuh-e-Patorgi area. 

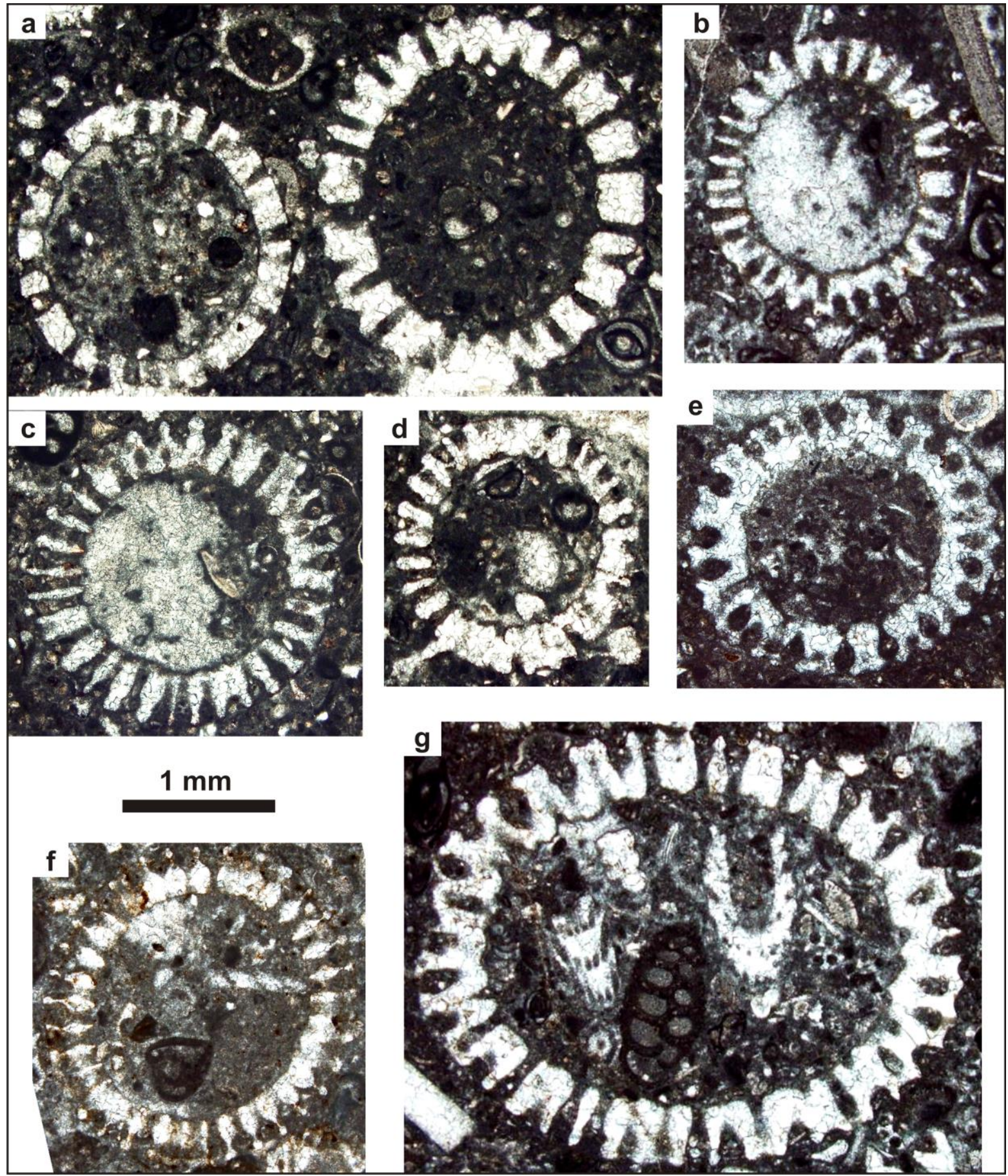

Fig. 6 Dissocladella? chahtorshiana n. sp. from Selandian carbonates of Kuh-e-Chah Torsh, Central Iran. a-f, transverse sections, partly slightly oblique. Note the different morphologies of the primaries, only slightly widening (a-b), or clubshaped (e-f). Secondary laterals partly visible in c, e, and f. g, oblique section. Thin-sections: Ah 185 (a, c-d), CT 4 (b, e-g).

Thanetian of France. The transverse section shown in plate 3 , fig. 1 , shows primaries that are widened proximally, displaying distinct swelling in the middle part, and two secondaries. This alga is distinctly smaller, displays a much lower $\mathrm{d} / \mathrm{D}$ ratio (about 0.38 ), a reduced number of laterals $(\mathrm{w}=16)$. Jodotella is different by its fertile ampullae set in clusters laterally to the primaries (Deloffre and Génot, 1982).

Dimensions (in mm): The main biometric parameters are compiled in Table 1. The maximum observed length of a thallus fragment is about $17.5 \mathrm{~mm}$ (Fig. 5E).
Palaeoenvironment: Dissocladella? chahtorshiana occurs in bioclastic packstones with various dasycladalean algae (e.g., Clypeina, Cymopolia), among some rather large taxa such as Rostroporella oviformis Segonzac (Fig. 5D), halimedacean algae (Fig. 5A-B) gastropods, benthic foraminifera, and rare fragments of corals. The association generally points to an open marine, outer platform environment of moderate water energy. A similar association including Rostroporella, Clypeina, Cymopolia div. sp., has been reported by Deloffre and Radoičić 
Table 1 Dimensions of Dissocladella? chahtorshiana n. sp. from the Paleogene of Iran (in mm, except ratio d/D). D: outer diameter; d: inner diameter; pmax: maximum diameter of primary laterals; l: length of primary laterals; p'max: maximum diameter of secondary laterals; l'max: maximum length of secondary laterals; h: verticil spacing; w: number of primary laterals in a verticil.

\begin{tabular}{|c|c|c|c|c|c|c|c|c|c|c|c|}
\hline no. & sample & D & & d & $d / D$ & pmax & l & $\mathbf{p}^{\prime}$ & $\mathbf{l}^{\prime}$ & h & $\mathbf{w}$ \\
\hline 1 & Ah 185 & 1.70 & & 1.30 & 0.76 & 0.14 & 0.24 & - & - & - & 36 \\
\hline 2 & Ah 185 & 2.10 & & 1.43 & 0.68 & 0.12 & 0.29 & 0.09 & 0.14 & - & 36 \\
\hline 3 & Ah 185 & 1.68 & & 1.15 & 0.69 & 0.11 & 0.24 & 0.08 & 0.10 & - & 32 \\
\hline 4 & Ah 185 & 2.00 & & 1.20 & 0.60 & 0.12 & 0.33 & 0.07 & 0.08 & - & 32 \\
\hline 5 & Ah 185 & 2.10 & & 1.48 & 0.70 & 0.17 & 0.29 & 0.06 & - & 0.19 & - \\
\hline 6 & Ah 185 & 1.50 & & 0.98 & 0.65 & 0.13 & 0.22 & 0.11 & 0.12 & - & - \\
\hline 7 & Ah 185 & 2.22 & & 1.21 & 0.55 & 0.18 & 0.33 & 0.11 & 0.09 & 0.20 & - \\
\hline 8 & Ah 185 & 2.20 & & 1.56 & 0.71 & 0.14 & 0.24 & - & - & - & 38 \\
\hline 9 & CT 4 & 2.00 & & 1.26 & 0.63 & 0.16 & 0.32 & 0.12 & 0.10 & - & 34 \\
\hline 10 & CT 4 & 1.86 & & 1.30 & 0.70 & 0.17 & 0.29 & 0.10 & 0.11 & - & - \\
\hline 11 & CT 4 & 1.68 & & 1.15 & 0.68 & 0.12 & 0.24 & - & - & - & 34 \\
\hline 12 & CT 4 & 2.11 & & 1.31 & 0.62 & 0.18 & 0.31 & 0.07 & - & - & - \\
\hline 13 & CT 4 & 2.98 & & 2.11 & 0.71 & 0.22 & 0.36 & 0.12 & - & - & 46 \\
\hline 14 & CT 4 & 2.18 & & 1.46 & 0.67 & 0.18 & 0.28 & 0.09 & 0.08 & - & 38 \\
\hline 15 & CT 4 & 1.63 & & 0.95 & 0.56 & 0.17 & 0.29 & - & 0.08 & 0.16 & - \\
\hline 16 & $2 \mathrm{pz} 29$ & 1.91 & & 1.37 & 0.71 & 0.15 & 0.22 & - & - & - & - \\
\hline \multicolumn{2}{|c|}{ range } & $\begin{array}{l}1.50 \\
2.98\end{array}$ & & $\begin{array}{l}0.95- \\
2.11\end{array}$ & $\begin{array}{l}0.55- \\
0.76\end{array}$ & $\begin{array}{ll}0.11 & - \\
0.22 & \end{array}$ & $\begin{array}{l}0.22- \\
0.36\end{array}$ & $\begin{array}{l}0.06- \\
0.12\end{array}$ & $\begin{array}{l}0.08- \\
0.14\end{array}$ & $\begin{array}{l}0.16- \\
0.2\end{array}$ & $\begin{array}{l}32 \\
46\end{array}-$ \\
\hline \multicolumn{2}{|c|}{ mean } & 1.99 & & 1.33 & 0.66 & 0.15 & 0.28 & 0.09 & 0.10 & - & 36 \\
\hline
\end{tabular}

(1978, p. 63) from the Paleocene of Slovenia and designated as "reefal environment".

\section{CONCLUSIVE REMARKS}

A new medium-sized Dasycladale is described as Dissocladella? chahtorshiana from Selandian-?early Thanetian micritic bioclastic packstones of Iran. Both localities, western margin of the Yazd Block, Central Iran, and the Sistan Suture Zone of Eastern Iran, belonged to the former Northern Neotethyan margin.

\section{ACKNOWLEDGEMENTS}

Thanks to the two reviewers Ioan Bucur (Cluj-Napoca) and Marc Conrad (Cologny) for helpful comments.

\section{REFERENCES}

Barani, F., Rashidi, K., Raisolssadat, S.N., Khazaee, M., 2017. Green Algae (Dasycladales) from Paleocene deposits in Western Birnjand (Grong section). Sedimentary Facies, 10 (1): 1-22 (in Persian with English abstract).

Barattolo, F., 1984. Osservazioni su Suppiluliumaella schroederi n. sp. (alghe Verdi, Dasicladali) del Cenomaniano del Matese (Appennino central, Italia). Bolletino della Società dei Naturalisti in Napoli, 92 (1983): 1-47.

Barattolo, F., 2002. Late Cretaceous-Paleogene Dasycladaleans and the K/T boundary problem. In: Bucur, I.I., Filipescu, S. (eds.), Research advances in calcareous algae and microbial carbonates, Proceedings of the $4^{\text {th }}$ IFAA Regional Meeting, Cluj Napoca, Romania, 29 August-5 September 2001, pp. 17-40.
Bucur, I.I., Granier, B., Schlagintweit, F., 2010. Steinmanniporella, a new dasycladale genus name for „Linoporella“ with two orders of laterals. Facies, 56: 317-321.

Deloffre, R., Poignant, A.F., Teherani, K., 1977. Algues calcaires de l' Albo-Aptien au Paléocene de l' Iran central. Bulletin des Centres de Recherches Exploration- Production Elf-Aquitaine, 1: 29-57.

Deloffre, R., Génot, P., 1982. Les Algues Dasycladales du Cénozoïque. Bulletin des Centres de Recherches Exploration-Production Elf-Aqutitaine, Mém. 4: 1247.

Deloffre, R., Radoičić, R., 1978. Algues calcaires (Dasycladales) du Paléocène de Slovénie (Yougoslavie). Bulletin de Centres Recherches ExplorationProduction Elf-Aquitaine, 2 (1): 61-95.

Eftekhar Nezad, J., Alavi- Naini, M., Lotfi, M., Aghanabati, A., Griffis, R.J., 1990. Geological map of Bandan, quaderangel map 1: 100000 series sheet 8152, Geological Survey of Iran.

Elliott, G.F., 1968. Permian to Palaeocene calcareous algae (Dasycladaceae) of the Middle East. Bulletin of the British Museum Natural History (Geology) Supplement, 4, 1-111.

Hottinger, L., 2014. Paleogene larger rotaliid foraminifera from the Western and Central Neotethys. Springer, Heidelberg, 196 pp.

Jaffrezo, M., 1975. Montenegrella corbarica n. sp., algue Dasycladacee du Neocomien des Corbières (France), avec une clé de détermination des Dasycla dacées jurassiques et crétacées a deux ordres de ramifications. Geologica Romana, 14: 155-163. 


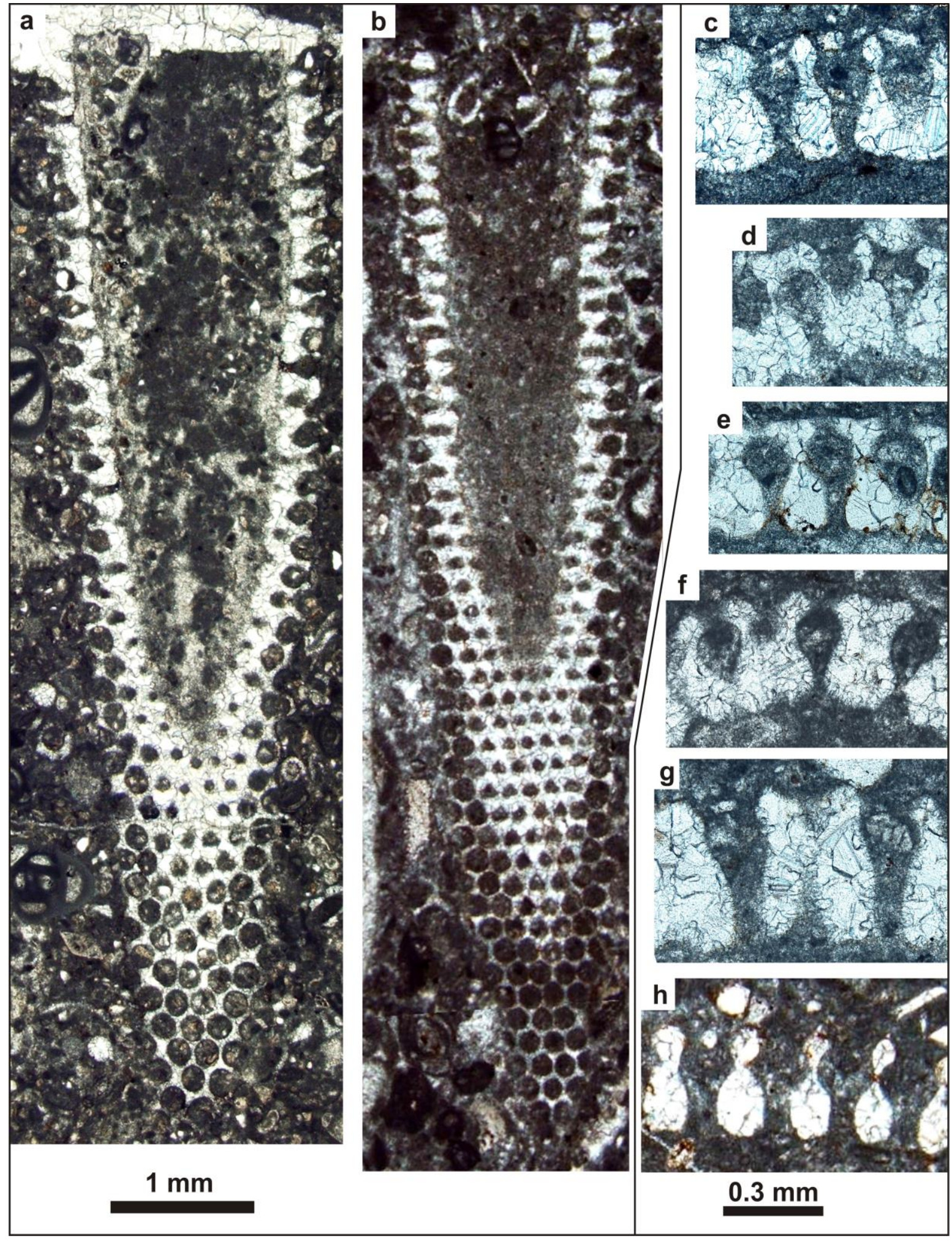

Fig. 7 Dissocladella? chahtorshiana n. sp. from Selandian carbonates of Kuh-e-Chah Torsh, Central Iran. a-b, longitudinal (upper part) and tangential (lower part) sections. Primaries are arranged in alternating position between successive verticils. In shallow tangential sections they are close-set and display rounded transverse outline. In deep tangential section (b, middle part) the transverse sections are rounded triangular. $\mathbf{c}-\mathbf{h}$, detailed views of the primaries, showing short secondaries. Thin-sections: Ah 185 (a-b), CT 4 (c-h). 

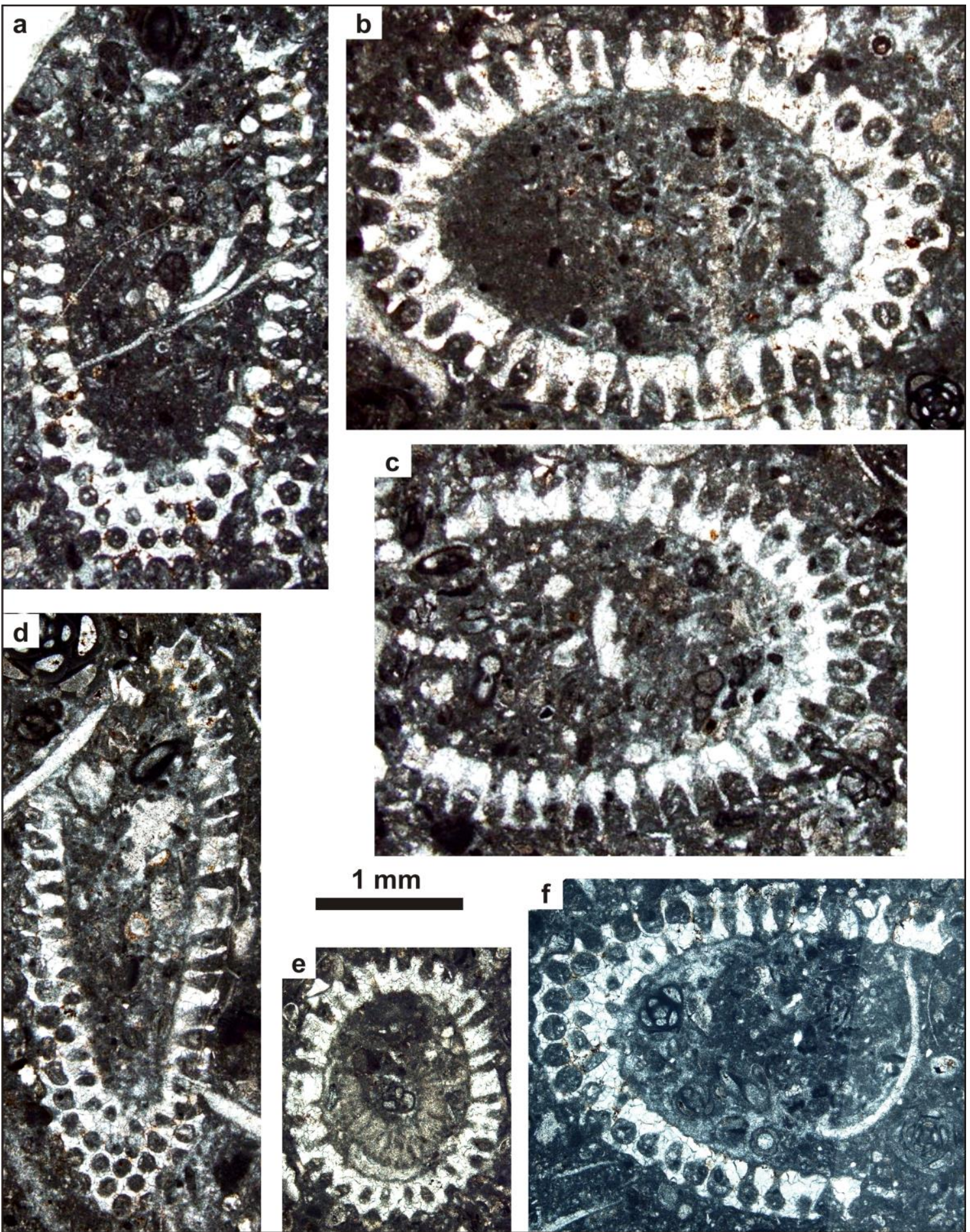

Fig. 8 Dissocladella? chahtorshiana n. sp. from Selandian carbonates of Kuh-e-Chah Torsh, Central Iran. a-f, variously oriented oblique sections. Note the claviform thallus in $\mathbf{d}$, and the presence of short secondaries visible in a (right side) or $\mathbf{f}$ (upper side). The holotype is shown in c. Thin-sections: CT 4 (a-d, f), Ah 185 (e).

James, G.A., Wynd, J.G., 1965. Stratigraphic Nomenclature of Iranian Oil Consortium Agreement Area. AAPG Bulletin, 49 (12): 2218-2232.

Kabanov, P., Anadón, P., Krumbein, W.E., 2008. Microcodium: an extensive review and a proposed nonrhizogenic biologically induced origin for its formation. Sedimentary Geology, 205: 79-99.

Kalantari, A., 1976. Microbiostratigraphy of the Sarvestan area, southwestern Iran. National Iranian Oil Company, 5, $130 \mathrm{p}$.
Khosrow-Tehrani, Kh., 1987. Late Maestrichtien and Paleocene deposits in south - southeast of Yazd area - central Iran. Journal of Science (University of Tehran), 16: 41-48.

Košir, A., 2004. Microcodium revisited: root calcification products of terrestrial plants on carbonate-rich substrates. Journal of Sedimentary Research, 74, 845857.

Kuss, J., Herbig, H.-G., 1993. Biogeograpgy, facies and taxonomy of Early Tertiary green algae from Egypt 
and Morocco. Bolletino della Società Paleontologica Italiana, Spec. vol. 1: 249-280.

Lasemi, Y., Afghah M., Arzaghi S., 2007. Facies Analysis and Sedimentary Environments of Sachun Formation in Kuh-e-Siah Section, Southeast of Sarvestan (Fars Province). Journal of Applied Geology, 3: 213218.

Majidifard, M.R., Vaziri, S.H., 2000. Geological map of Bahadoran (scale of 1:100.000) with an explanatory text. Report number 6952. Geological Survey of Iran, Tehran.

Mu, X., Wang, Y.-J., 1985. Some calcareous algae from the Eocene of Tingri, Xizang, China. Acta Micropaleontologica Sinica, 2: 289-296.

Nabavi, M.H., 1972. Geological map of Yazd, 1: 250.000. Map. No H9, Geological Survey of Iran, Tehran.

Papazzoni, C.A., Ćosović, V., Briguglio, A., Drobne, K., 2017. Towards a calibrated larger foraminifera biostratigraphic zonation: Celebrating 18 years of the application of Shallow Benthic Zones. Palaios, 32: 15.

Radoičić, R., 1991. Dissocladella gracilis n. sp. (Dasycladales) from the Thanetian of Majevica mountain (NE Bosnia, Dinarides). Revue de Paléobiologie, 10: 309-313.

Radoičić, R., 1998. Two new Paleocene Dasycladales from Slovenia. Annales Géologique de la Peninsule Balkanique, 62: 103-121.

Radoičić, R., Conrad, M.A., Carras, N., 2005. Observations on Neomeris cretacea var. undulata Raineri followed by Dissocladella bonardii, n. sp. (Dasycladales, green algae). Revue de Paléobiologie, 24 (1): 311-317.

Rahaghi, A., 1978. Paleogene biostratigraphy of some parts of Iran. Publications of the National Iranian Oil Company Geological Laboratories, 17: 1-161.

Rahaghi, A., 1980. Tertiary faunal assemblage of QumKasan, Sabzewar and Jahrum areas. National Iranian Oil Company, Geological Laboratories, 8: 64 p.

Rahaghi, A., 1983. Stratigraphy and faunal assemblage of Paleocene-Lower Eocene in Iran. National Iranian Oil Company, Geological Laboratories, 10.73 p.

Rao, L.R., Pia, J., 1936. Fossil algae from the uppermost Cretaceous beds (the Niniyur Group) of the Trichinopoly district, S. India. Mem Geol Surv India, Pal Indica, N.S. 21(4): 1-49.

Rivandi, B., Moosavizadeh, S.M.A., 2015. Larger Benthic Foraminifera from the Paleocene sediments in the Chehel-Kaman Formation, North-East Iran. Open Journal of Geology, 5: 224-229.

Robles-Salcedo, R., Vicedo, V., Parente, M., Caus, E., 2019. Canalispina iapygia gen. et sp. nov.: the last Siderolitidae (Foraminiferida) from the upper Maastrichtian of southern Italy. Cretaceous Research, 98: 84-94.
Schlagintweit, F., Rashidi, K., 2019 in press. Serrakielina chatorshiana gen. et sp. nov., and other (larger) benthic Foraminifera from Danian-Selandian carbonates of Mount Chah Torsh (Yazd Block, Central Iran). Microplaeontology.

Schlagintweit, F., Wilmsen, M., 2014. Orbitolinid biostratigraphy of the top Taft Formation (Lower Cretaceous of the Yazd Block, Central Iran). Cretaceous Research, 49: 125-133.

Salahi, A., El Hedeny, M., Vinn O., Rashwan, M., 2018. Sclerobionts on organic substrates from the Late Paleocene Chehel-Kaman Formation, Kopet-Dagh Basin, NE Iran. Annales Societatis Geologorum Poloniae, 88: 291-301.

Segonzac, G., 1976. Dasycladacées nouvelles ou peu connues du Thanetian des Pyrénées. Bulletin de la Société d'Histoire Naturelle de Toulouse, 112 (1-2): 123-136.

Segonzac, G., 1979. Algues calacires du Thanétien d'Eséranza (Aude) (Dasyckadacées, Corallinacées). Bulletin de la Société d'Histoire Naturelle de Toulouse, 115 (3-4): 439-463.

Serra-Kiel, J., Hottinger, L., Caus, E., Drobne, K., Ferrandez, C., Jauhri, A.K., Less, G., Pavolvec, R., Pignatti, J., Samso, J.M., 1998. Larger foraminiferal biostratigraphy of the Tethyan Paleocene and Eocene. Bulletin de la Société Geologique de France, 169: 281-299.

Sirel, E., 1999. Four new genera (Haymanella, Kayseriella, Elazigella, and Orduella) and one new species of Hottingerina from the Paleocene of Turkey. Micropaleontology, 45: 113-137.

Sirel, E., 2012. Seven new larger benthic foraminiferal genra from the Paleocene of Turkey. Revue de Paléobiologie, 31: 267-301.

Sokač, B., Nikler, L., 1973. Calcareous algae from the Lower Cretaceous of the environs of Nikšić, Crna Gora (Montenegro). Paleontologia Jugoslavica, 13: 7-57.

Takin, M., 1972. Iranian geology and continental drift in the Middle East. Nature, 23: 147-150.

Tirrul, R., Bell I.R., Griffis, R.J., Camp, V.E., 1983. The Sistan Suture Zone of eastern Iran. Geological Society of America Bulletin, 94: 134-150.

Zanchi, A., Zanchetta, S., Garazanti, E., Balini, M., Beraa, F., Mattei, M., Muttoni, G., 2009. The Cimmerian evolution of the Nakhlak-Anarak area, Central Iran, and its bearing on the reconstruction of the history of the Eurasian margin. In: Brunet, M.F., Wilmsen, M., Granath, J.W. (eds) South Caspian to Central Iraan Basin. Geological Society London, Special Publications, 312: 261-286. 